\title{
GREAT POWERS' MILITARY BASES AND STRENGTHENING SECURITY IN THE URBANIZED WORLD
}

\author{
Zlatko KUZMANOV, PhD \\ Army of the Republic of Macedonia / Ministry of Defense \\ E-mail:asz6mak@yahoo.com \\ Goran ZENDELOVSKI, PhD \\ Faculty of Philosophy - Institute of Security, Defense and Peace \\ E-mail: zendelovski@fzf.ukim.edu.mk
}

\begin{abstract}
The great powers spend enormous resources to achieve their national and geo-strategic interests. They have the capacity to protect national interests beyond their national borders. Such a need for expansion and achievement of a strategic advantage is in correlation with the maintenance and upgrading of powerful armed forces. One way to ensure a global presence in regions of interest is to open military land, sea and air bases. In recent years, the great powers, in particular the United States of America, have reaffirmed the strategic commitment to strengthen their military presence in the region of Southeast Europe. With this approach, emphasis is placed on security policies, which should ensure the achievement of national and regional political and economic interests.
\end{abstract}

Key words: great powers, USA, geostrategic interests, military power and military bases.

\section{Introduction}

The key security, defense and military strategies of the United States unambiguously emphasize the need to protect the United States national interests everywhere in the world. To accomplish this goal, the United States integrates the political, economic and military elements of the national power. The U.S. Army, as a representative of military power, aims to remain the dominant force in the world and to ensure that the balance of forces will remain in its favor. This requires a global presence of military forces in key regions around the world in order to deter, respond to crises, and to defeat the enemy if necessary. According to military strategies and doctrines, opening military bases in the world should provide a permanent military presence and readiness for a quick and effective response. Bearing in mind that allies are needed to open military bases, it is vital to build a global network of partners that as the sole force should create conditions to secure national and regional interests. In international relations and in the rivalry to achieve geostrategic interests, besides the U.S., other great countries have come to realize the role of military bases. Other major powers such as China, Russia, Great Britain and France 
have such a strategic and doctrinal approach. The role, types and purpose of military bases, as well as their large share in military budgets, their prevalence and repositioning, are the main motive for even a deeper research into this area.

\section{A brief historical overview of the creation of military bases}

The history of the appearance of U.S. military bases begins in the late 19th century after Spain was defeated in the Spanish-American war. After the victory, the Americans established control over the important port of Subic Bay in the Philippines ${ }^{38}$, which due to the favorable location allowed control of the sailing of Chinese ships. While on the opposite side, in the Caribbean region, the U.S. established supremacy by opening military bases in Guantanamo and Puerto Rico. During World War II, the U.S. got an approval from their allies England and France to open military bases on their territory. However, immediately after the end of the war, the U.S. continued to open new military bases in other European countries, such as Belgium and Iceland. The first decade after the end of World War II, in order to disrupt the spread of the influence of the Communist political system and the Cold War, the U.S. opened military bases in Germany, Italy, South Korea and Japan. However, this did not end the spread of the U.S. bases network, as they started to emerge even in countries from the Middle East ${ }^{39}$, in order to provide a strategic presence near countries that were considered aggressive and undemocratic, such as Iran and Iraq, and to provide security in a region rich in oil.

\section{Reasons for establishing military bases}

First of all, what is meant by the term "military base"? As a source of data, we will use Pentagon reports, bearing in mind that most of the world's military bases belong to the United States. According to the criteria and definitions of the U.S. Department of Defense, so that a military facility can be included in the "Bases Structure Report" (DoD Base Structure Report, 2017), i.e. to be considered as a larger military base, the base must cover an area larger than 10 hectares and to have a value that exceeds 10 million dollars. The Pentagon's definitions make a distinction among the following notions: a specific military location, a military installation, a military base, a camp, a station, a center, accommodation facilities, ground or underground structures (runways, roads, railroad, pipeline, fence, electrical installation), anchorages, including a rented space that is controlled and supports the Pentagon activities.

The distinction can also be done according to other criteria. In terms of the size of the military bases and the time of their existence, we can divide them into: large/permanent bases (such as some of the U.S. military bases on the territory of Germany, Great Britain, Guam Island in the Pacific and Japan); operating/temporary bases (such as some military bases in Italy, Aus-

\footnotetext{
38 The Philippines is located in the Far East region or in a region that covers eastern and southeastern Asia and is of strategic importance to the US. East Asia geographically includes: China, Japan, Taiwan, Korea, and Vietnam. Southeast Asia covers Cambodia, Malaysia, Myanmar, Thailand, Indonesia and the Philippines.

39 The region which geographically covers: Turkey, Israel, Jordan, Syria, Lebanon, Iraq and Egypt.
} 
tralia, Kuwait, Iraq and South Korea) and military facilities, installations and platforms (e.g. radar stations, communication centers, analytical centers, warehouses, etc.). According to the purpose and type of forces that use them, the military bases can be: land bases, naval bases, air bases, naval air bases and satellite surveillance bases. As we can see, there are several categories of military facilities. However, since the intention of this paper is to elaborate on the place and the role of the larger military facilities, that is, the military bases, we will continue to use the terms - military bases, installations and military facilities.

The administration in Washington, in all previous National Security Strategies, has clearly declared their determination to protect the U.S. national interests anywhere in the world. The place and role of the U.S. Army in achieving these goals is essential. In the past, empires spread through the conquest of colonies, while in the recent times, the largest military forces spread their influence through military bases. The choice of locations for opening military bases, their purpose and their role is related to the achievement of economic, political, military and security goals. Often, all these goals coincide with the efforts for military presence in regions rich in strategic resources (oil, gas, water resources, rare mineral resources, etc.) but of poor, underdeveloped and unstable countries, i.e. regions which are considered risky and endangering for regional and international security. However, the reasons for opening military bases can certainly be sought in the rivalry, the competitiveness and the desire for domination among super powers and blocks, which have the potential and intention to play a bigger role in international relations. Critics would say that it is not uncommon for the proclaimed struggle against "terror" and the incitement to "democratic values" by the most powerful countries to be actually used to hinder competition and rivalry among them.

If we go back to the beginnings and the development of the Cold War between the two blocks, that is, the U.S. and the USSR (later Russia), we can conclude that strategies (in which nuclear arsenals played the main role) developed from the initial strategy for "nuclear equilibrium" towards the strategy for "nuclear equality and parity", then moved to a "core necessity strategy" and the current strategy for "flexible response" (National Security Strategy of the USA, 2017). In all these strategies, military presence outside the country embodied into opening military bases plays a significant role. It is clear that "this game" includes not only the U.S., which are certainly the most dominant, but also other great powers such as Russia, China, Great Britain, France and others. The prevalence of the U.S. military bases throughout the world will be explained in more detail in the continuation of this paper.

\section{U.S. military bases in the world}

Overseas, the U.S. Army employs 250,000 to 300,000 uniformed personnel, and the number of employees in the Ministry of Defense is similar. 44,446 local people who sign contracts for the needs of the Ministry of Defense should be added to this number. The U.S. Army has more than 686 bases in 70 countries around the world, not including about 6,000 military facilities in the United States (Vine, 2015). Due to the complexity and the large number of military installations, the data in some official sources are different. 
In the table below, we will present the data published in the Department of Defense Base Structure Report for 2017 (DoD Base Structure Report, 2017).

Table 1 - Data on the number of U.S. military bases.

$10 n$ the territory of 50 states, one district and 8 out of 14 territories in the Caribbean and the Pacific and in 46 other sovereign countries in the world)

\begin{tabular}{|l|c|c|c|c|c|c|}
\hline Area & Army & Navy & BB & Marine corpus & $\begin{array}{c}\text { Washington Head- } \\
\text { quarters Service }\end{array}$ & Total \\
\hline USA & 1588 & 790 & 1528 & 172 & 89 & 4167 \\
\hline Territories & 39 & 62 & 9 & 0 & 0 & 110 \\
\hline Other countries & 199 & 125 & 170 & 23 & 0 & 517 \\
\hline Total: & $\mathbf{1 8 2 6}$ & $\mathbf{9 7 7}$ & $\mathbf{1 7 0 7}$ & $\mathbf{1 9 5}$ & $\mathbf{8 9}$ & $\mathbf{4 7 9 4}$ \\
\hline
\end{tabular}

Similar figures are reported in the 2015 U.S. Department of Defense Base Structure Report (Department of Defense Base Structure Report, 2015) and the Defense Manpower Data Center (Mereli, 2015), which indicated that there are 587 bases in 42 countries in the world, mostly located in Germany (181 bases with 50,000 personnel), in Japan (122 bases with about 10,000 personnel) and in South Korea ( 83 bases with about 28,000 personnel). According to the Pentagon, of all the listed military bases, 20 of them are large, 16 are medium, 482 are small, and 69 are the remaining military installations. According to the U.S. Department of Defense Base Structure Reports (Department of Defense Base Structure Report , 2014), in all military bases and military installations in the country and overseas, there are 44,870 barracks, hangars, hospitals and other buildings, as well as additional 4,844 objects that are leased. It is estimated that the value of the existing military bases and military installations overseas is around \$113 billion, while replacing all existing bases, including those in the U.S. territory, would require more than $\$ 590$ billion. One of the most prominent researchers in the United States, David Vine, points out that the maintenance of U.S. bases and troops overseas for 2014 cost the United States from $\$ 85$ to $\$ 100$ billion, while total base and military costs have been estimated from $\$ 160$ billion to $\$ 200$ billion (Vine, 2015).

From the data presented, it is obvious that the United States has a large number of military bases overseas. To illustrate this conclusion, we will provide more detailed data on some of them.

In Germany, the U.S. Army has about 180 military bases with over 50,000 troops. The U.S. European Command is located in Stuttgart. The Ramstein Military Air Base is the largest U.S. base in Europe and is located in the city of Ramstein-Miesenbach in the Kaiserslautern region (Ramstein Air Base). It is the headquarters of the U.S. Air Force for Europe and Africa and the headquarters of the Allied Air Force Command. This base has nuclear weapons. Near the base, the largest U.S. military hospital outside the U.S. borders is located. Another major base is the Spangdahlem military base. This base accommodates 4,800 personnel from the 52nd Fighter Wing, which includes F-16 fighting aircrafts (Spangdahlem Air Base). The Grafenwoehr military training area is the largest military facility which spreads on more than 223 square kilometers 
in the Bavarian region. This range has a tradition of 108 years and it is used by more than 6000 troops. The 7th Army Joint Multinational Training Command is responsible for the training of members of the U.S. Army at this range (Army Technology, 2018).

In Italy, the U.S. Army has 58 military bases in which more than 11,000 troops are stationed. In recent years, new military bases have been opened on Sicily.

In the Philippines, there are seven smaller temporary U.S. Army military installations and platforms with about 6,000 troops, officially known as "units for carrying out military exercises".

Over 28,000 troops have been stationed in 85 bases and military installations in South Korea since 1957.

Over 50,000 U.S. troops are stationed on the territory of Japan, in over 30 military bases and installations which are under a special command of U.S. Forces Japan. The main command is located at the Yokota Air Base, located on the east of Tokyo. The Misawa Air Base is located on the north of Tokyo and operates the most modern 5th generation jet fighters. On the southernmost island of Okinawa, there are several military bases which were opened after the end of World War II, including the Butler naval base and the Futenma naval air base.

In Iraq, the U.S. Army still controls 6 permanent and 4 new temporary military bases. These are: the Fallujah military base, west of Baghdad; LSA Anaconda military base, north of Baghdad with about 20,000 personnel; the new military base at the Baghdad International Airport; the Talil air base near Nazaria; the military base in the western deserts near the border with Syria and the military base at Bushur, to the north in the Kurdish region.

In Qatar, there is a strategically important Al Udeid Air Base, located south of the city of Doha (The 379th Air Expeditionary Wing). This base is the main U.S. air base in the Middle East. It stations the Combined Air Operations Center of the U.S. Army Central. From here, the coordination of military operations in Iraq and Afghanistan is carried out, as well as the anti-terrorist actions in Syria and Iraq. The base accommodates about 10,000 U.S. troops, fighter jets, tanks, armored vehicles, Patriot missile defense systems and other equipment.

In the small African state of Djibouti, which is strategically important, the U.S. Army has the only permanent military base in Africa (Watson, 2017). Most of the operations against al-Qaeda and other extremist and terrorist groups in the region are being conducted from this air base. The base stations more than 2,000 troops.

In the Pacific region, the American Island of Guam is a strategically important military stronghold. There are two military bases on this island: Andersen Air Force Base and Apra Harbor (The United States Indo-Pacific Command-USINDOPACOM). These bases are of strategic significance for the United States for the wider Eurasian region. The bases hold military aircrafts of all types for missile strikes along the Pacific coast of Eurasia.

According to the above mentioned, we see that the prevalence of military bases is high. Some critically-minded American researchers say that the real reasons for building a new ring of U.S. bases along the equator is to expand the U.S. Empire and boost its military domination in the world.

In the scheme below, we can see the aforementioned base ring. 


\section{Security}

\section{Map 1 - Mapping the U.S. expansionism..$^{40}$}

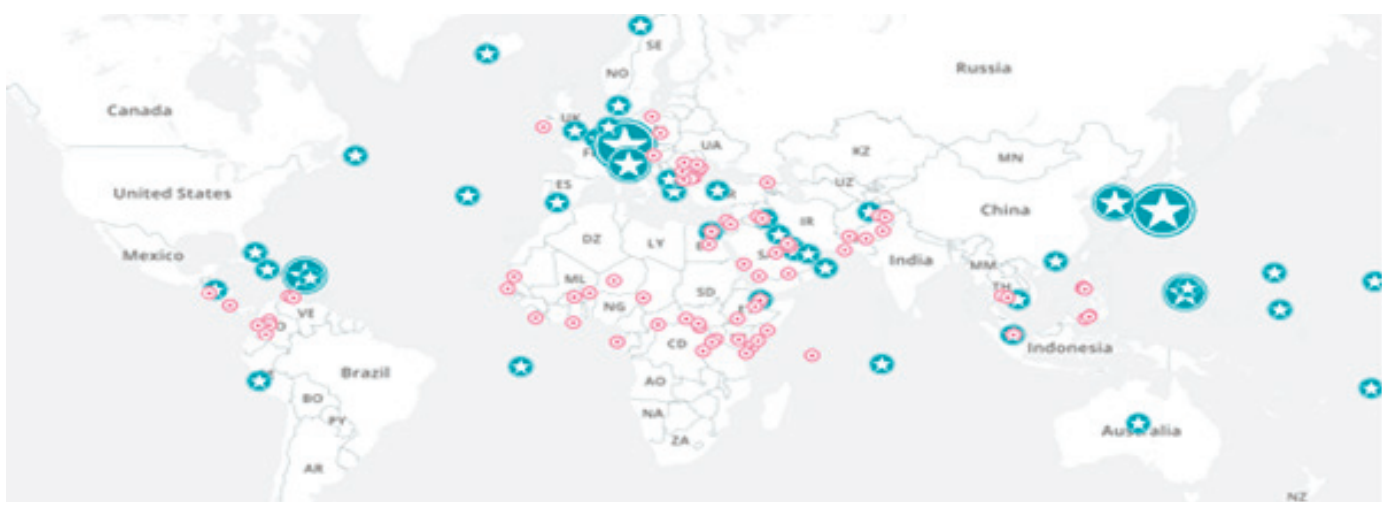

Source: „Mapping American Expansionism“, Saturday, September 12, 2015.

Available at: http://googlemapsmania. blogspot.com.

The prevalence of U.S. military power is mirrored by its navy. The U.S. navy forces are grouped around 11 aircraft carriers, symbolically named after the names of U.S. presidents, congressmen and senators, and nine ships - amphibians, which are also aircraft or helicopter carriers (List of aircraft carriers of the United States Navy, 2018). The mighty military U.S. Army can also be illustrated with the organizational structure of its forces, which are deployed in the following six strategic commands (U.S. DoD), around the world: US Central Command, based in the Shaw Air Force Base in South Carolina, responsible for the region of North East Africa, the Middle East, Central and South Asia; United States Northern Command, based in Fort Sam, Houston Texas, responsible for North America and Canada; the United States Southern Command, based in Fort Sam, Houston, Texas, responsible for South America; United States European Command, based in Lucius D. Klei Kaserne, Wiesbaden, Germany, responsible for Europe and Russia; United States African Command, headquartered in Caserma Ederle, Vicenza, Italy, responsible for Africa, and the United States Pacific Command, based in Fort Shafter, Hawaii, responsible for the Pacific. In addition to these six strategic commands, the structure of the U.S. Army also includes the United States Cyber Command and the United States Strategic Command.

40 The United States bases' spreadsheet is an interactive map showing military bases and 'Lily Pad' (temporary security platforms / locations). "Lily pad" are small, often secret military installations, primarily intended for anti-terrorist actions in the world. The big blue circles on the chart show the countries in the world in which the United States has military bases. For example, 174 bases in Germany. Smaller red circles show individual locations on the US Lily Pad bases. Data for the scheme come from many sources. However, the secret nature of smaller military installations and the lack of full transparency means that there may be even smaller military bases and exantations. 


\section{Map 2 - The zones of responsibility of the U.S. Army six strategic commands.}

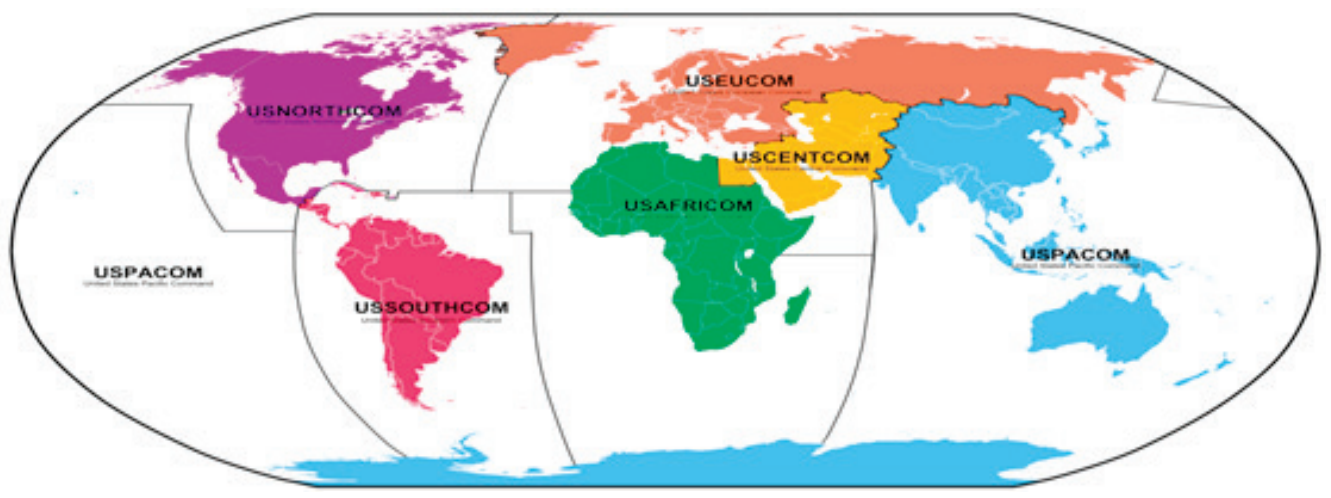

Source:The Unified Command Plan, U.S. Department of Defense. Available at: https://archive.defense.gov/ucc/.

The role of military bases overseas, in addition to its military intention and purpose, is also to provide profits to the civilian industry, especially to the production of military weapons and equipment, companies that provide various services based on contracts, as well as firms that need to build and maintain facilities in military bases. A big part of the U.S. economy has earnings and interest to cooperate with the U.S. Army.

After the 9/11 terrorist attacks in the U.S., President Bush's administration was tasked to develop plans for a "Preventive War" against enemy states, extremists, and terrorists. To impose a "Preventive War", a global presence or deployable military forces is needed near the critical and conflicting points in the world, where they can act very quickly once they receive information about it. Former Secretary of State Colin Powell called it "our new family of bases". Military strategists have identified a situation they call the "arc of instability", which according to them stretches from the Andes region to South America (Colombia), then through North Africa to the Middle East (Afghanistan, Iraq, Kuwait, Israel, Qatar, Kyrgyzstan and Uzbekistan) and to the Philippines and Indonesia in Asia (Johnson, 2015). It can be noted that this arc extends more or less through countries that have not been called "The Third World" for a long time. However, it is quite clear today that along this arc there are the key reserves of oil and gas in the world. So, the strategists in the Pentagon certainly did not map the "arc of instability" in this way by accident, in whose imaginary length were established the largest number of military bases and installations. In order to reposition the power of the great powers in the last decade, the United States is preparing plans for expansion, but at the same time reducing the number of military bases in the country and around the world. Thus, according to the Pentagon's plans from 2016, it was planned to reduce the number of ground military bases by $1 / 3$ and the number of air bases in the U.S. by $1 / 4$ (DoD Base Structure Report, 2016). 


\section{Security}

\section{Military bases of other major military forces}

In order to protect their own national interests and expand the influence in the world, other large and developed countries have also opened military bases. Considering that Russia and China are the biggest competitors to the United States in military aspect, we will provide data for these two countries as well.

\section{Russia}

For the last several years, due to the economic problems that the country has been facing, the defense budget is not at the desired level. The budget for 2017 was $\$ 66.3$ billion or 3.3\% from the GDP, while for 2018 the budget was 3\% from the GDP (SIPRI Military Expenditure Database). However, we are witnessing that Russia continues to undertake political, diplomatic and military activities to strengthen military capabilities and to open new air and naval bases in various countries and regions throughout the world. Russian officials say the purpose of the bases is to improve the safety of Russian ships trading in international waters, to provide protection against piracy attacks and to be used to service ships, while the air bases would be used as fueling stations. It is clear that such expansion primarily has a military purpose, that is, creating conditions for strategic matching the measures already taken by the U.S., since Russia vigorously opposes the expansion of U.S. military power close to its borders. Most of the Russian military bases are in the former Soviet republics or as they are called in Russia, "in the near neighborhood". Thus, the military base in Gyumri and the military air base in Yerevan are located in Armenia. In Belarus, there is an Early Warning Radar Station in Hantsavichy and the Maritime Communication Center in Vileyka. In Georgia, after the Russian-Georgian war in 2008, Russia deployed significant forces (about 3,500 troops) to a military base in South Ossetia and a military base in Abkhazia (about 4,500 troops). In Kazakhstan near Lake Balkhash, Russia has developed a Radar Station, an anti-ballistic missile testing area in Sary-Shagan and the Baikonur Cosmodrome. In Kyrgyzstan, there is the Kant Air Base which has the Communication Center, the Torpedo Testing Area and the Seismographic Center. In Moldova, Russia maintains significant military forces in the Transnistria region, to preserve peace after this region proclaimed unilateral autonomy from Moldova. In Syria, Russia has the Tartus naval base and the Khmeimim air base. Russia's 201st military base is located in Tajikistan, in Vietnam the naval air base in Cam Ranh, in Crimea the famous naval base Sevastopol and the Belbek air base, which, after the annexation of the island in 2014, Russia considers as Russian territory (Sharkov, 2018). 


\section{Map 3 - Current military installations of Russia (without Crimea).}

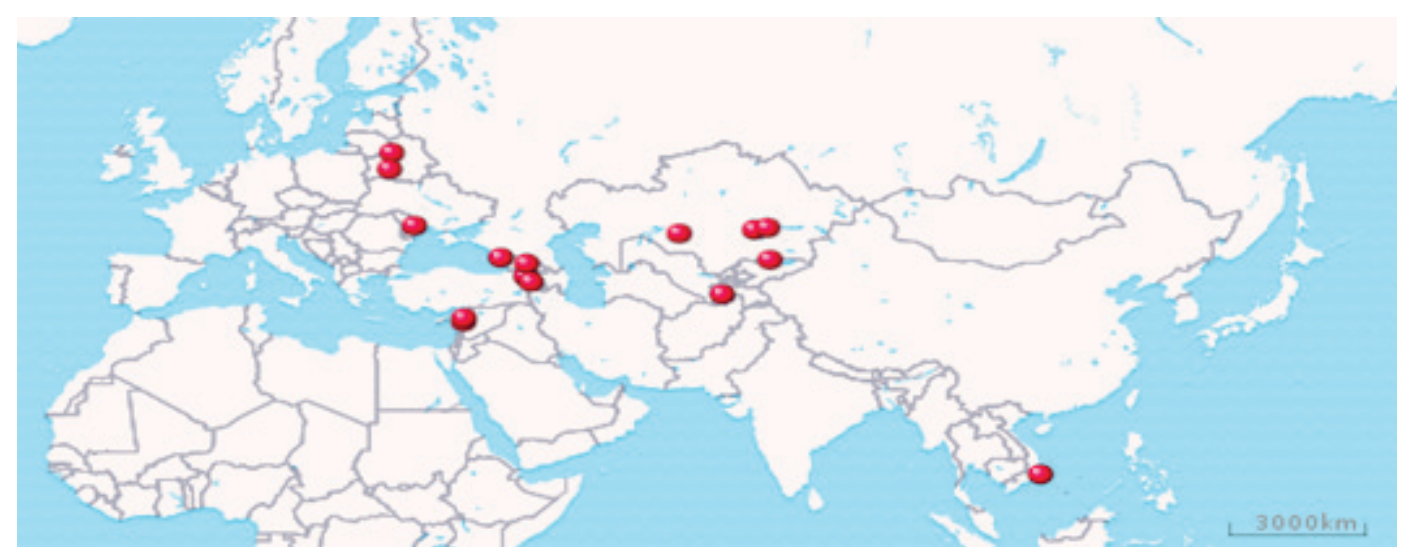

Source: List of Russian military bases abroad.

Available at:https://en wikipedia.org/ wiki/List_of_Russian_military_bases_abroad.

According to statements by the Defense Minister Shoygu and the Foreign Minister Sergey Lavrov, Russia announces possible opening of new military bases. The center of gravity is in the western hemisphere, Cuba in particular, where the Intelligence Radar Center would be reopened after being closed in 2002. New bases will be opened on the territory of Argentina, as well as Eritrea, a country in the Horn of Africa, where a Logistic Center would be opened (Russian forces abroad, 2003). In the Balkans, officially Russia has not opened its own military base, but there are different interpretations of the role and purpose of the Russian-Serbian humanitarian center that was opened in 2012 in Nis, Serbia. Officials from Serbia and Russia reject the allegations that the center has a military purpose while according to some information that come from western countries it is assumed that the center can in fact be a "camouflaged base" for intelligence operations.

\section{China}

China's rapid economic development continues. It is the second largest economy in the world and the first in terms of industrial production since it provides $25 \%$ of the world's economic growth. China's direct investment in other countries has crossed $\$ 1$ billion, while its assets abroad are estimated at $\$ 7$ billion (Fakti, Glob0tpor, 2018). China's "One Belt One Way" initiative, in addition to its economic goal, intends to provide China geopolitical dominance. Of course, the military component is added to this. Economic growth has a positive impact on allocating funds for defense needs. According to the Stockholm International Peace Research Institute (SIPRI Military Expenditure Database), in 2017 China's military budget was \$228 billion, the second largest in the world, after the United States. China is rapidly investing in the production of high-tech combat assets, such as submarines, ships, aircraft carriers (in May 2018, the first 
self-produced aircraft carrier was tested), stealth planes and other military equipment. The concept of "costal defense" in China was abandoned in the late 1980s and replaced with a new concept called "off-shores water defense". With this strategic decision, the development of China's navy is directed towards the high seas (Nekic, 2011). China strengthens its military positions especially in the sensitive region of the South China Sea and along the waterways to transport Chinese goods to Africa, Western, Central and Eastern Europe.

Military expansion is also demonstrated by opening of new military bases. Thus, on August 1, 2017, China opened a military base in Djibouti. The African State of Djibouti is on the strategically important maritime route from the Gulf of Aden, through the Red Sea to the Suez Canal, through which China transports most of its exports to Europe. The base accommodates 2,000 soldiers, and it has a capacity for 10,000 soldiers (Elazar, 2017). It is intended to support Chinese Army missions abroad, to provide humanitarian aid to Africa and West Asia, to supply Chinese units, to support military patrol vessels and to carry out humanitarian and rescue missions at sea. The naval part of the "One Belt One Way" initiative starts from the port of Gwadar in Pakistan. In 2018, China signed an agreement with Pakistan to use this strategically important port where the Chinese goods through the land route from China mainly arrive (Pauley and Shad, 2018). Of course, the port serves as a naval military base. The importance of this region for China is shown by the fact that near the port of Jiwani, which is $80 \mathrm{~km}$ west of the Gwadar naval base in Pakistan, there is a military air base for which China at the beginning of 2018 signed an agreement with Pakistan for its use and modernization. It is important to mention that in the vicinity of the ports of Gwadar and Giwanni, in the Gulf of Oman, there is a naval military base in Chabahar on the territory of Iran, which is a joint military base of Iran, India and Afghanistan. Another Chinese naval base also located along the maritime route of the "One Belt One Way" initiative is in Hambantota, Sri Lanka. In recent years, China has been rapidly building new military bases in the troubled region of the South and East China Sea. China as well as other countries in the region (Vietnam, Brunei, Malaysia and the Philippines) claims the right that the area around the groups of islands of Paracel and Spratly is their territory. Roughly a third of the total maritime transport takes place throughout this strategically important region. China has its naval and air military bases on some of the islands in the region of the Malacca Strait and in the Bay of Bengal. Such is the naval military base in the port city of Sittwe in Burma (Myanmar), to which China has built a gas and oil pipeline. The next Chinese naval military base is Chittagong in Bangladesh (Nekic, 2011). China's expansion and the economic and military conquest of new territories reach to South America. Using the effects of the global financial crisis, and in order to satisfy its appetites for oil, iron, soy and copper, China has heavily invested in the Latin American region. The trade between China and the Latin American countries and Caribbean in 2017 reached $\$ 244$ billion, surpassing the United States. China has invested more than $\$ 20$ billion in Argentina in order to help repay large debts, stabilize the national currency and restore the country's obsolete rail network. In return, Argentina allowed China to build a military control station for satellite and space missions in Patagonia. The space station, worth \$50 million, started operating in March 2018 (Tweed and Leung, 2018). 


\section{Map 4 - Location of Chinese and other bases in the Indian and Pacific oceans.}

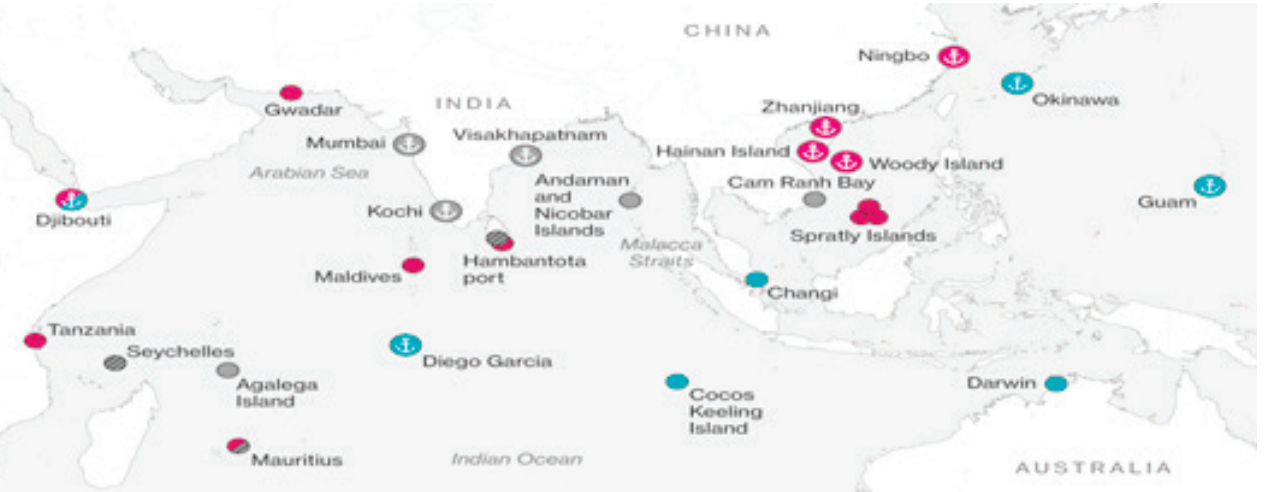

Source:Chinese Naval Expansion Hits High Gear. Available at: https://tradingyourownway.com/chinese-naval-expansion/. (Legend: Red circles denote Chinese military bases, blue circles are American and gray ones are Indian. Circles with lines denote possible bases).

\section{Conclusion}

The United States remains the dominant political, economic and military force in the world. However, its leadership is seriously jeopardized by the rapidly growing economic and military development of China, as well as by the continuing rivalry with Russia, which is mostly expressed in a military context. Worldwide, the United States is the largest military superpower, which for the needs of the defense and the military allocates 3 times more than the second-ranked China and 10 times more than the third-ranked Russia. In this paper we have seen the scope of the widespread distribution of the U.S. military bases and military installations around the world, which dominates compared to its main competitors.

We can conclude that the great powers provide the global presence and domination both through the deployment of military capabilities. In addition to security and political reasons, the selection of locations for the deployment of military bases in the world is primarily for the purpose of achieving economic interests. When we analyze locations of military bases, we come to the conclusion that they are directly related to providing security and protecting critical strategic infrastructure, such as oil pipelines, gas pipelines, maritime trade routes, land routes and rail corridors, places and regions rich in strategic energy resources (oil, gas, minerals, water resources, renewable energy resources, etc.).

A small number of large military forces (besides the United States) also use aircraft carriers, using them as "mobile military bases" to achieve military, political, security and economic interests. The great powers, by placing military power in direct correlation with the pursuit of strategic economic interests, are in some way trying to justify extreme high costs in military and defense budgets. In the past, the great Empires spread their interests through powerful military forces. This process has not ceased to the present, but on the contrary, is constantly being upgraded. 


\section{References}

1. Base Structure Report FY 2014 (2014). Department of Defense, USA.

2. Base Structure Report FY 2015 (2015). Department of Defense, USA.

3. Base Structure Report FY 2016 (2016). Department of Defense, USA.

4. Base Structure Report FY 2017 (2017). Department of Defense, USA.

5. "Chinese Naval Expansion Hits High Gear". Available at: https://tradingyourownway. com/ chinese-naval-expansion/.

6. Elazar, G.(2017). "China in the Red Sea: The Djibouti Naval Base and the Return of Admiral Zheng $\mathrm{He}$. Available at: https://besacenter.org/perspectives-papers/china-red-sea-djibouti/. [Accessed on 25.11. 2018].

7. Grafenwohr Army Base. Available at: https://www.army-technology.com/projects/ grafenwohrarmybase. . Accessed on 02.12.2018].

8. Johnson, C. (2015). „America occupies the planet: The grim realities of our endless War on Terror".

9. Know Your Military. Available at: https://www.defense.gov/know-your-military/combatant-commands [Accessed on 18.11.2018].

10. List of aircraft carriers of the United States Navy. Available at: https://en.wikipedia.org/ wiki /List_of_aircraft_carriers_of_the_United_States_Navy [Accessed on 20.11.2018].

11. List of Russian military bases abroad. Available at:https://en wikipedia.org/wiki/List_ of_Russian_military_bases_abroad [Accessed on 23.11.2018].

12. Lutz, C.(2009). The bases of empire: the global struggle against US military posts". New York University Press.

13. "Mapping American Expansionism"Saturday, September 12, 2015. Available at: http:// googlemaps mania. blogspot.com. [Accessed on 22.05.2018].

14. Mereli, A. (2015). "These are all the countries where the US has a military presence". Available at: https//qz.com/. Defense Manpower Data Center - DMDC [Accessed on 29.10.2018].

15. National Security Strategy of the United States of America (2010). President of the USA.

16. National Security Strategy of the United States of America (2002). President of the USA.

17. National Security Strategy of the United States of America (2006). President of the USA.

18. National Security Strategy of the United States of America (2015).President of the USA.

19. National Security Strategy of the United States of America (2017). President of the USA.

20. Nekic, D. (2011). "Uspon Kineske ratne mornarice iz regionalne i globalnu ratnu mornaricu".

21. Pauley, L. and Shad H. (2018)."Gwadar: Emerging Port City or Chinese Colony?" Available at: https://thediplomat.com [Accessed on 02.12.2018].

22. Ramstein Air Base. Available at: https://www.ramstein.af.mil [Accessed on 02.12.2018].

23. Российские войска за рубежом [Russian forces abroad] (in Russian). kommersant.ru. 18 March 2003. Available at: https://www.kommersant.ru/ [ Accessed on 02.11.2018].

24. Sharkov, D. "Russia's Military Compared to the U.S.: Which Country Has More Military Bases Across the World?" Available at: https://www.newsweek.com/russias-military-compared/military-bases [Accessed on 6/3/18]. 
25. The 379th Air Expeditionary Wing. Available at:http://www.afcent.af.mil/ Units/379th-Air-Expeditionary-Wing/. [Accessed on 25.11.2018].

26. The SIPRI Military Expenditure Database, 1949-2017 (2018). [Accessed on 01.12.2018].

27. The Unified Command Plan. U.S. Department of Defense. Available at: https://archive. defense. gov/ucc/ [Accessed on 12.11.2018].

28. The United States Indo-Pacific Command (USINDOPACOM) Available at: https://www. pacom.mil/.US Indo - Pacific Command [Accessed on 22.11.2018].

29. Tweed, D. and Leung A. (2018). "China is Making a Bold - Military Power Play". Available at: https://www.bloomberg.com [Accessed on 02.12.2018].

30. Vine, D. (2015). "Base lines and military projections". Available at: geographical imaginations.com/tag/base-structure-report/[Accessed on 28.10.2018].

31. Vine, D. (2015). "Base Nation: how US military bases abroad harm America and the world". Metropolitan Books.

32. Watson, K. (2017). "Where does the U.S. have troops in Africa, and why? Available at: https://www.cbsnews.com/news/, CBS NEWS, October 23 [Accessed on 20.11.2018]. 